\title{
Sodium-Potassium Pump, Ion Fluxes, and Cellular Dehydration in Sickle Cell Anemia
}

\author{
Hiroko Izumo, Stephanie Lear, Mark Williams, Robert Rosa, and Franklin H. Epstein \\ Charles A. Dana Research Institute, Harvard-Thorndike Laboratory of Beth Israel Hospital, Department of Medicine, \\ Harvard Medical School and Beth Israel Hospital, Boston, Massachusetts 02215
}

\begin{abstract}
We studied the role of the sodium-potassium pump in erythrocytes of 12 patients with sickle cell anemia (SS). Ouabain-binding sites per cell and pump-mediated $\mathbf{R b} / \mathbf{K}$ uptake were significantly higher in SS patients than in white or black controls. Ouabainresistant $\mathbf{R b} / \mathrm{K}$ influx was also greater than in normal controls or patients with sickle cell trait.

Deoxygenation of SS erythrocytes increased ouabain-sensitive $\mathbf{R b} / \mathrm{K}$ influx without altering ouabain binding, presumably as the consequence of an increase in the passive influx of sodium. Deoxygenation increased mean corpuscular hemoglobin concentration (MCHC) by 5.5\%, and studies of the density distribution of SS cells indicated an increase in highly dense fractions known to contain sickled erythrocytes. Ouabain prevented the rise in MCHC and reduced the percentage of dense cells.

These findings indicate a magnified role for the sodium-potassium pump in the pathophysiology of SS erythrocytes and suggest that its inhibition might prove useful in therapy.
\end{abstract}

\section{Introduction}

The genetic defect in sickle cell anemia (SS) ${ }^{1}$ results in the synthesis of an abnormal hemoglobin, hemoglobin S (Hb S), which upon deoxygenation polymerizes into a gel state. This gelation process produces the characteristic sickle deformation in red cells and predisposes to microcirculatory occlusion and subsequent ischemic damage. The pathogenesis of sickling depends strongly on the intracellular concentration of deoxyhemoglobin $S(1,2)$. Sickling is therefore enhanced by dehydration of erythrocytes, which produces a rise in mean corpuscular hemoglobin concentration (MCHC).

In addition to the abnormality in hemoglobin, SS erythrocytes exhibit changes in membrane permeability, possibly owing to alterations in the membrane cytoskeleton $(3,4)$. It has been well documented that deoxygenated sickle erythrocytes exhibit increased $\mathrm{Na}$ and $\mathrm{K}$ fluxes, with net cellular $\mathrm{Na}$ gain and $\mathrm{K}$ loss (5-10). However, the effect of such changes on red cell water content and MCHC is still controversial. The contributions of the various components of ion flux during sickling, such as the sodium-potassium pump and the $\mathrm{Na}-\mathrm{K}-\mathrm{Cl}$ cotransport pathway,

Presented in part at the American Federation for Clinical Research, May 1985. (1985. Clin. Res. 33:343a.)

Received for publication 4 November 1986.

1. Abbreviations used in this paper: AA, normal erythrocyte; AS, sickle cell trait; BSKG, phosphate-buffered saline with potassium and glucose; DDC, density distribution of cells; Hb S, hemoglobin S; MCHC, mean corpuscular hemoglobin concentration; SS, sickle cell anemia.

J. Clin. Invest.

(c) The American Society for Clinical Investigation, Inc.

$0021-9738 / 87 / 06 / 1621 / 08 \quad \$ 1.00$

Volume 79, June 1987, 1621-1628 have not been fully elucidated, owing in part to methodological variation and to the heterogeneity of the red cell population in sickle cell blood.

We have evaluated the sodium-potassium pump in sickle erythrocytes by means of an ouabain-binding assay and ${ }^{86} \mathrm{Rb}$ uptake and have explored the relation of pump inhibition to cell volume. The activity of the sodium-potassium pump is increased above normal in oxygenated SS cells and further increased by deoxygenation. In deoxygenated cells, inhibition of the pump by ouabain results in a reduction of $\mathrm{MCHC}$ and the proportion of dense cells, consistent with cell swelling. This suggests a possible role for cardiac glycosides in anti-sickling therapy.

\section{Methods}

Subjects. Venous blood was obtained from 12 patients with SS, 6 with sickle cell trait (AS), and 40 white and 10 black normotensive control subjects, aged 15-45 yr, none of whom were taking cardiac glycosides or diuretics or had recently received blood transfusions. The blood was then analyzed by the following tests.

Ouabain binding and $R b / K$ uptake. $10 \mathrm{ml}$ of blood was drawn from each subject into a heparinized syringe for the measurement of $\left[{ }^{3} \mathrm{H}\right]$ ouabain binding and ${ }^{86} \mathrm{Rb}$ uptake by previously described techniques (11). The plasma and buffy coat were separated by centrifugation and discarded; the remaining erythrocytes were washed three times with 10 vol of $\mathrm{MgCl}_{2}$ solution (112 mM). After a final wash in ouabain-binding buffer, containing in $\mathrm{mM}: \mathrm{NaCl}, 140 ; \mathrm{CaCl}_{2}, 1 ; \mathrm{MgCl}_{2}, 1$; Hepes, 20 ; dextrose, $5 \%$; $\mathrm{pH} 7.40$, red cells were suspended in the same buffer at a hematocrit of $5-10 \%$.

To measure ouabain binding to erythrocytes, triplicate $200-\mu \mathrm{l}$ aliquots of the red cell suspension were added to $50 \mu \mathrm{l}$ of a mixture of $0.5-1.0$ pmol of $\left[{ }^{3} \mathrm{H}\right]$ ouabain (New England Nuclear, Boston, MA; sp act, $17-$ $18 \mathrm{Ci} / \mathrm{mM}$ ) and unlabeled ouabain, so that the total concentration of the ligand ranged from 80 to $120 \mathrm{nM}$. This concentration of ouabain has been shown to saturate the specific-binding sites of human erythrocytes when incubated at $37^{\circ} \mathrm{C}$ for $1 \mathrm{~h}$ (11). In a single pilot experiment, SS erythrocytes incubated with the same concentration of radiolabeled ouabain also displayed saturation kinetics by $1 \mathrm{~h}$ at $37^{\circ} \mathrm{C}$. Nonspecific binding of $\left[{ }^{3} \mathrm{H}\right]$ ouabain was measured in the presence of $0.1 \mathrm{mM}$ unlabeled ouabain. After a 60 -min incubation at $37^{\circ} \mathrm{C}$ in a shaking water bath, the cells were washed three times in 1-ml volumes of ice-cold $\mathrm{MgCl}_{2}$, after which $200 \mu$ l of $5 \%$ TCA were added and the mixture was centrifuged for $15 \mathrm{~min}$ at $10,000 \mathrm{~g}$. The clear supernatant containing the released radioactivity was then drained and counted in $5 \mathrm{ml}$ of Biofluor in a liquid scintillation spectrometer.

Potassium influx was estimated by measuring the uptake of ${ }^{86} \mathrm{Rb}$ into erythrocytes $\left(\mathrm{Rb} / \mathrm{K}\right.$ influx). Previous studies indicate that ${ }^{86} \mathrm{Rb}$ can be used as an analog of potassium in human erythrocytes (12-14). After the red cells were washed with $\mathrm{MgCl}_{2}$ and suspended in ouabain-binding buffer, $4 \mathrm{mM} \mathrm{KCl}$, and $\sim 10^{5} \mathrm{cpm}$ of the $\mathrm{K}$ analog ${ }^{86} \mathrm{RbCl}$ (New England Nuclear; sp act, $1.0 \mathrm{mCi} / \mathrm{mg}$ ), was added to each tube. The $\mathrm{Na}, \mathrm{K}$-ATPasemediated uptake of ${ }^{86} \mathrm{Rb}$ was calculated as the difference between total radioactivity taken up by triplicate aliquots with and without $0.1 \mathrm{mM}$ ouabain. After a 10 -min incubation at $37^{\circ} \mathrm{C}$ in a shaking water bath, the cells were washed with ice-cold $\mathrm{MgCl}_{2}$. Intracellular radioactivity was released by $5 \%$ TCA and counted in the supernatant after centrif- 
ugation for $15 \mathrm{~min}$ at $10,000 \mathrm{~g}$. The results were expressed as nanomoles of $\mathrm{K}^{+} / 10^{9}$ red blood cells per hour, using the assumption that ${ }^{86} \mathrm{Rb}$ is a tracer for the influx of stable $\mathrm{K}^{+}$, present at a concentration of $4 \mathrm{mM}$ in the suspending medium.

The portion of ${ }^{86} \mathrm{Rb}$ uptake that is insensitive to ouabain and inhibited by furosemide is mediated through $\mathrm{Na}, \mathrm{K}$-cotransport present in human red blood cells $(15,16)$. To evaluate $\mathrm{Na}, \mathrm{K}$-pump-independent $\mathrm{Rb} / \mathrm{K}$ uptake further, triplicate samples of red cells were incubated with 0.1 $\mathrm{mM}$ ouabain alone, or both ouabain and $1 \mathrm{mM}$ furosemide, under experimental conditions analogous to those described above.

Intracellular electrolyte concentrations. In the course of the foregoing experiments, red cells from heparinized venous blood were separated from plasma and buffy coat by centrifugation and washed three times with an isosmotic solution of $112 \mathrm{mM} \mathrm{MgCl}$. Before ouabain-binding and $\mathrm{Rb} / \mathrm{K}$ uptake studies, $400-\mu \mathrm{l}$ aliquots of packed erythrocytes were removed and recentrifuged at $10,000 \mathrm{~g}$ to remove the remaining supernatant. A $200-\mu l$ aliquot of packed cells was transferred in a wide-bore pipette to $9.8 \mathrm{ml}$ of deionized water to induce hemolysis. $\mathrm{Na}$ and $\mathrm{K}$ concentrations were measured in triplicate by flame photometry, after centrifugation to pellet cell membrane fragments.

Ouabain-binding and $R b / K$ uptake after nitrogen incubation. Incubation of SS blood under nitrogen was used as a means of deoxygenating red cells, thereby inducing sickling. $30 \mathrm{ml}$ of heparinized venous blood were required for this study. The erythrocytes were separated, washed, and resuspended as described earlier. After aliquots of the red cell suspension in ouabain-binding buffer were removed for baseline studies of ouabain binding, $\mathrm{Rb} / \mathrm{K}$ uptake, and intracellular electrolyte concentration, the remainder of the suspension, at a hematocrit of $10 \%$, was divided into two portions for deoxygenation. In one of these, destined for subsequent measurement of intracellular electrolytes and $\mathrm{Rb} / \mathrm{K}$ uptake, $\mathrm{KCl}$ was added to produce a final concentration in the medium of $4 \mathrm{mM}$. Both were then exposed for $2 \mathrm{~h}$ in a shaking water bath at $37^{\circ} \mathrm{C}$ to $100 \%$ nitrogen humidified by bubbling through an isotonic solution at $37^{\circ} \mathrm{C}$. Deoxygenation was confirmed by measuring $\mathrm{P}_{\mathrm{O}_{2}}$ with a blood gas analyzer $\left(\mathrm{P}_{\mathrm{O}_{2}}<18 \mathrm{mmHg}\right)$. The $\mathrm{pH}$ of the suspension was stable during the incubation. After $2 \mathrm{~h}$ of nitrogen incubation, the cell suspension was studied by ouabain binding and $\mathrm{Rb} / \mathrm{K}$ assay techniques; particular care was taken to expose the red cells continuously to nitrogen during these procedures. Intracellular electrolyte concentrations were measured after deoxygenation as described above.

Separation of erythrocytes by density gradients. In a separate study, $20 \mathrm{ml}$ of heparinized blood was placed in a mixture of $9 \%$ Ficoll and 33.9\% Hypaque and centrifuged to separate red cells. After centrifugation, erythrocytes were resuspended in phosphate-buffered saline with $\mathrm{K}$ and glucose (BSKG; in mM: $\mathrm{NaCl}, 134 ; \mathrm{Na}_{2} \mathrm{HPO}_{4}, 16 ; \mathrm{NaH}_{2} \mathrm{PO}_{4}, 4 ; \mathrm{KCl}$, 5; glucose, 11; osmolarity, 295 mOsm; pH 7.4) to a hematocrit of $20 \%$. Stractan gradients were prepared according to the method described by Corash et al. (17) with minor modifications (18). Stractan II (arabinogalactan) was passed through both cation and anion exchange resins. Stractan was then added to a solution containing (per $100 \mathrm{ml}$ Stractan): bovine serum albumin, $3 \mathrm{~g}$; glucose, $100 \mathrm{mg} ; \mathrm{KH}_{2} \mathrm{PO}_{4}, 2.85 \mathrm{mM}$; $\mathrm{K}_{2} \mathrm{HPO}_{4}, 12.15 \mathrm{mM} ; \mathrm{MgCl}_{2}, 112 \mathrm{mM}$. The $\mathrm{pH}$ and osmolality of the Stractan solution were adjusted to 7.4 and $291 \mathrm{mOsm}$. The Stractan solution was then diluted with BSKG to achieve the desired densities. For control blood, three layers of Stractan with densities of 1.110, 1.101, and 1.092 were used, whereas denser Stractan solutions were required for the blood of sickle cell patients because of the presence of heavier cells (densities of 1.150,1.110, and 1.101 were used). Red cells suspended in BSKG were layered on top of Stractan gradients and centrifuged at $4^{\circ} \mathrm{C}$ at $52,000 \mathrm{~g}$ for $45 \mathrm{~min}$. Three fractions of red cells, top, middle, and bottom, were collected and washed separately three times with $\mathrm{MgCl}_{2}$ and once with ouabain-binding buffer. For each fraction, reticulocytes were counted in smears stained with methylene blue. Sickled forms were counted unstained. Ouabain-binding and $\mathrm{Rb} / \mathrm{K}$ uptake assays were then performed on each fraction as described above.

Density distribution of cells (DDC). The DDC technique has been used in various erythrocyte disorders to determine the distribution of cells by relative density. Normal erythrocytes exhibit a narrow range of densities. However, the DDC of SS blood reflects the heterogeneity of the red cell population including denser sickled cells, as well as less dense, younger cells containing a high proportion of reticulocytes (19).

The method, as described by Danon and Marikovsky (20), requires two phthalate esters as separating fluid, methyl phthalate (specific gravity, 1.189 ), and di-n-butyl phthalate (specific gravity, 1.0416), which were used to prepare a series of solutions of $\mathbf{2 0}$ different specific gravities, ranging from 1.062 to 1.138 , in increments of $0.004 .10 \mathrm{ml}$ of heparinized blood were drawn for use in these experiments. One microhematocrit tube was dipped into each of the different solutions until a column of slightly more than $5 \mathrm{~mm}$ was obtained. The remainder of the tube was then filled with heparinized venous blood, sealed, and spun at $12,000 \mathrm{~g}$ for $15 \mathrm{~min}$ in a refrigerated centrifuge. A set of 20 capillary tubes for each blood sample was then arrayed in order of decreasing specific gravity of the separating liquids. The results were plotted with decreasing specific gravity of the phthalate solution on the abscissa and the percentage of red cells that had passed through the separating liquid on the ordinate.

$M C H C$. The calculation of $\mathrm{MCHC}$ is used as an approximation of cell water content and is based upon measured hematocrit and hemoglobin, according to the equation: $\mathrm{MCHC}=\mathrm{Hb}(\mathrm{g} / \mathrm{dl}) /$ packed cell volume (\%) $\times 100$. Packed cell volume was determined by high-speed centrifugation of blood in a heparinized microhematocrit capillary tube for 6 min to minimize the potential for excess plasma trapping by sickle erythrocytes. Hemoglobin was measured spectrophotometrically by the cyanohemoglobin method, which includes all hemoglobin and hemoglobin derivatives except possibly sulfhemoglobin, using $5 \mathrm{ml}$ of Drabkin's reagent for $0.02 \mathrm{ml}$ of venous blood (21).

To evaluate the effects of deoxygenation on MCHC and DDC, 10 $\mathrm{ml}$ of heparinized blood was gassed in an Erlenmeyer flask in a shaking water bath at $37^{\circ} \mathrm{C}$ for $2 \mathrm{~h}$ with either air or nitrogen with $5 \% \mathrm{CO}_{2}$.

Statistics. Results are expressed as mean \pm SE. Comparison of two samples was done by Student's $t$ test. Multiple samples were compared by analysis of variance and the Newman-Keuls test.

\section{Results}

Na,K transport characteristics (Table I). Binding of $\left[{ }^{3} \mathrm{H}\right]$ ouabain to human red blood cells is a high-affinity saturable process; the receptor for $\left[{ }^{3} \mathrm{H}\right]$ ouabain in the erythrocyte, as in other cells, is the Na-K-ATPase pump. In these experiments, the number of $\left[{ }^{3} \mathrm{H}\right]$ ouabain-binding sites is determined at a saturating concentration of the ligand, at which $\mathrm{Na}, \mathrm{K}$ pump-mediated ion transport is completely inhibited (11).

The mean value of ouabain binding was significantly higher in sickle cell patients $\left(0.81 \pm 0.05 \mathrm{pmol} / 10^{9}\right.$ cells) than in white controls $(0.47 \pm 0.02 ; P<0.001)$. Black controls had an even lower value for ouabain binding $(0.38 \pm 0.02)$ than white controls. Patients with sickle cell trait had a value $(0.38 \pm 0.04)$ that did not differ significantly from that of either control group.

The mean ouabain-sensitive $\mathrm{Rb} / \mathrm{K}$ uptake was significantly higher in sickle cell patients $\left(189.6 \pm 15.8 \mathrm{nmol} / 10^{9} \mathrm{cells} / \mathrm{h}\right)$ than in white controls $(124.8 \pm 4.1 ; P<0.001)$. As in the ouabainbinding assay, this value was even lower in black controls $(96.9 \pm 5.6)$ than in whites. There were no significant differences between patients with sickle trait and either control group. The ouabain-insensitive $\mathrm{Rb} / \mathrm{K}$ uptake was four to five times higher in red cells of patients with SS than in either white or black controls $(P<0.001)$. Thus, sickle cell patients have a greater number of $\mathrm{Na}, \mathrm{K}$ pump units as well as increased pump activity, as measured by ouabain-sensitive $\mathrm{Rb} / \mathrm{K}$ uptake. In addition, ouabain-insensitive $\mathrm{Rb} / \mathrm{K}$ uptake is increased in sickle cells as compared with normal erythrocytes.

The major portion of pump-independent ouabain-insensitive $\mathrm{Rb} / \mathrm{K}$ uptake can be inhibited by furosemide and its derivatives and represents $\mathrm{Na} / \mathrm{K} / \mathrm{Cl}$ cotransport $(22,23)$. Furosemide-sen- 
Table I. Studies of Ouabain-binding Rb/K Uptake and Intracellular Electrolyte Concentrations of Erythrocytes

\begin{tabular}{|c|c|c|c|c|c|}
\hline & Ouabain binding & $\begin{array}{l}\text { Ouabain-sensitive } \\
\mathrm{Rb} / \mathrm{K} \text { uptake }\end{array}$ & $\begin{array}{l}\text { Ouabain-insensitive } \\
\mathrm{Rb} / \mathrm{K} \text { uptake }\end{array}$ & $\begin{array}{l}\text { Intracellular } \\
\mathrm{Na} \text { concentration }\end{array}$ & $\begin{array}{l}\text { Intracellular } \\
\mathrm{K} \text { concentration }\end{array}$ \\
\hline & pmol $/ 10^{9}$ cells & nmol/10 $10^{\circ}$ cells $/ h$ & & mEq/liter cells & mEq/liter cells \\
\hline White control & $\begin{array}{l}0.47 \pm 0.02 \\
(n=40)\end{array}$ & $\begin{array}{l}124.8 \pm 4.1 \\
(n=40)\end{array}$ & $\begin{array}{l}50.3 \pm 2.0 \\
(n=40)\end{array}$ & $\begin{array}{c}5.9 \pm 0.3 \\
(n=21)\end{array}$ & $\begin{array}{l}88.1 \pm 2.1 \\
(n=21)\end{array}$ \\
\hline Black control & $\begin{array}{l}0.38 \pm 0.02^{*} \\
(n=10)\end{array}$ & $\begin{array}{l}96.9 \pm 5.6^{*} \\
(n=10)\end{array}$ & $\begin{array}{l}39.1 \pm 7.3^{*} \\
(n=6)\end{array}$ & $\begin{array}{l}7.8 \pm 0.7^{*} \\
(n=10)\end{array}$ & $\begin{array}{l}81.9 \pm 4.5 \\
(n=10)\end{array}$ \\
\hline SS & $\begin{array}{l}0.81 \pm 0.05^{\ddagger} \\
(n=12)\end{array}$ & $\begin{array}{l}189.6 \pm 15.8^{\ddagger} \\
(n=12)\end{array}$ & $\begin{array}{l}225.6 \pm 16.9^{\ddagger} \\
(n=12)\end{array}$ & $\begin{array}{l}19.0 \pm 1.6^{\ddagger} \\
(n=12)\end{array}$ & $\begin{array}{l}60.0 \pm 2.9^{\ddagger} \\
(n=12)\end{array}$ \\
\hline AS & $\begin{array}{l}0.38 \pm 0.04 \\
(n=6)\end{array}$ & $\begin{array}{l}107.3 \pm 8.5 \\
(n=6)\end{array}$ & $\begin{array}{l}77.7 \pm 13.4 \\
(n=6)\end{array}$ & $\begin{array}{l}8.1 \pm 0.8^{*} \\
(n=6)\end{array}$ & $\begin{array}{l}76.9 \pm 2.8 \\
(n=6)\end{array}$ \\
\hline
\end{tabular}

Values are mean \pm SE. * Significantly different from white controls $(P<0.01)$. ${ }^{\ddagger}$ Significantly different from all other groups $(P<0.01)$.

sitive $\mathrm{Rb} / \mathrm{K}$ uptake, measured in the presence of $10^{-4} \mathrm{M}$ ouabain, was significantly greater in erythrocytes of patients with SS (129.2 \pm 12.3$)$ than those of in controls $(40.6 \pm 3.4 ; P<0.001)$.

Intracellular electrolytes (Table I). Intracellular sodium concentration was significantly higher in erythrocytes of sickle cell patients $(19.0 \pm 1.6 \mathrm{mEq} / \mathrm{liter}$ cells $)$ than in those of any control group $(P<0.001)$. Cell sodium was significantly higher in normal black subjects $(7.8 \pm 0.7)$ and persons with sickle trait $(8.1 \pm 0.8)$ than in white controls $(5.9 \pm 0.3)(P<0.01)$. Intracellular concentration of potassium was significantly lower in SS erythrocytes than in the red cells of any of the control populations $(P<0.001)$.

$N a, K$ transport characteristics of erythrocytes separated by density gradients (Tables II and III). It is known that reticulocytes, which are young red cells, have enhanced active and passive transport mechanisms for sodium and potassium as compared with mature red cells (24-28). Reticulocytes constitute the lightest fraction of the red cell population, whereas sickled erythrocytes are the heaviest cells. To evaluate the contribution of reticulocytes to the increase in ouabain binding and $\mathrm{Rb} / \mathrm{K}$ uptake in the sickle cell population, erythrocytes were separated by Stractan solutions according to cell density. The ouabain binding and $\mathrm{Rb} / \mathrm{K}$ uptake assays were then performed on each of the three cell fractions. Different densities of Stractan were used for sickle cell blood and for control blood because of the larger proportion of heavier cells in SS blood (see Methods). The cells of the middle fraction in sickle cell blood correspond in density to the cells of the bottom fraction in control blood because of the different densities of Stractan used.

The sodium and potassium transport parameters for control
(AA) and SS red cells are summarized in Tables II and III, respectively. In SS blood, there was a greater percentage of reticulocytes, as expected, pooled in the top fraction where significantly greater ouabain binding and pump-mediated $\mathrm{Rb} / \mathrm{K}$ uptake was found than in the middle or bottom fractions $(P<0.01)$. In contrast, there was no difference in transport characteristics among the top, middle, and bottom fractions of control red cells.

The heaviest fraction of sickle cell blood (with only $1.4 \pm 0.36 \%$ reticulocytes) had a ouabain-binding capacity that was not significantly different from that of the lightest layer of control blood (with $2.8 \pm 0.43 \%$ reticulocytes) but a ouabain-sensitive $\mathrm{Rb} / \mathrm{K}$ uptake that was much higher than any of the three fractions of control blood $(P<0.01)$. To analyze further the nature of pump-mediated $R b / K$ flux, the ouabain-inhibited $R b /$ $\mathrm{K}$ influx per ouabain-binding site, which represents the pump activity per pump unit, was calculated. In SS blood, this value was significantly higher for the bottom fraction of cells (with more sickled erythrocytes) than the top fraction (with more reticulocytes) $(P<0.01)$, implying an increased rate of turnover of each pump unit in the heaviest cells.

The effect of deoxygenation on cation transport of sickle erythrocytes (Table IV). In control erythrocytes, there was no significant change in any of the transport parameters after nitrogen incubation. In SS cells, ouabain binding, although elevated before deoxygenation $\left(0.69 \pm 0.04 \mathrm{pmol} / 10^{9}\right.$ cells $)$, did not change after nitrogen incubation $(0.65 \pm 0.05)$. However, deoxygenation caused a doubling of ouabain-sensitive $\mathrm{Rb} / \mathrm{K}$ uptake $(P<0.01$ as compared with the pre- $\mathrm{N}_{2}$ value). This indicates that while

Table II. Na,K Transport Characteristics of AA Erythrocytes Separated by Stractan Gradients

\begin{tabular}{|c|c|c|c|c|c|c|}
\hline Fraction & Density & Reticulocyte & $\begin{array}{l}\text { Ouabain } \\
\text { binding }\end{array}$ & $\begin{array}{l}\text { Ouabain-sensitive } \\
\text { Rb/K uptake }\end{array}$ & $\begin{array}{l}\text { Ouabain-sensitive } \\
\frac{\mathrm{Rb} / \mathrm{K} \text { uptake }}{\text { Ouabain-binding }} \times 10^{-3}\end{array}$ & $\begin{array}{l}\text { Ouabain-insensitive } \\
\mathrm{Rb} / \mathrm{K} \text { uptake }\end{array}$ \\
\hline & specific gravity & $\%$ & $\mathrm{pmol} / 10^{9} \mathrm{cells}$ & $\mathrm{nmol} / 10^{\circ}$ cells $/ \mathrm{h}$ & $h^{-1}$ & $\mathrm{nmol} / 10^{\circ}$ cells/h \\
\hline Top & 1.092 & $2.8 \pm 0.43$ & $0.505 \pm 0.026$ & $130.0 \pm 6.5$ & $0.261 \pm 0.020$ & $62.9 \pm 5.5$ \\
\hline Middle & $1.092-1.101$ & $0.55 \pm 0.22$ & $0.464 \pm 0.025$ & $139.8 \pm 4.6$ & $0.311 \pm 0.015$ & $72.0 \pm 9.1$ \\
\hline Bottom & $1.101-1.110$ & $0.029 \pm 0.028$ & $0.458 \pm 0.032$ & $132.8 \pm 10.5$ & $0.294 \pm 0.029$ & $61.0 \pm 12.5$ \\
\hline
\end{tabular}

$n=7$. Values are mean \pm SE. Red cells suspended in BSKG at a hematocrit of $20 \%$ were layered on top of Stractan gradients of the specific gravities indicated in the table and centrifuged at $4^{\circ} \mathrm{C}$ for $45 \mathrm{~min}$ at $52,000 \mathrm{~g}$. Three fractions of red cells were collected separately and washed with $\mathrm{MgCl}_{2}$ and ouabain-binding buffer before determining their reticulocyte count, ouabain binding, and $\mathrm{Rb} / \mathrm{K}$ uptake. 
Table III. Na,K Transport Characteristics of SS Erythrocytes Separated by Stractan Gradients

\begin{tabular}{|c|c|c|c|c|c|c|c|}
\hline Fraction & Density & $\begin{array}{l}\text { Reticulocyte } \\
(\%)\end{array}$ & $\begin{array}{l}\text { Sickled cells } \\
(\%)\end{array}$ & Ouabain binding & $\begin{array}{l}\text { Ouabain-sensitive } \\
\text { Rb/K uptake }\end{array}$ & $\begin{array}{l}\text { Ouabain-sensitive } \\
\mathrm{Rb} / \mathrm{K} \text { uptake/ } \\
\text { ouabain-binding } \times 10^{-3}\end{array}$ & $\begin{array}{l}\text { Ouabain-insensitive } \\
\text { Rb/K uptake }\end{array}$ \\
\hline & specific gravity & $\%$ & $\%$ & $\mathrm{pmol} / 10^{\circ}$ cells & nmol/10 cells/h & $h^{-1}$ & nmol/10 cells/h \\
\hline Top & $1.092-1.101$ & $15.2 \pm 4.15$ & $0.12 \pm 0.06$ & $1.153 \pm 0.132$ & $311.6 \pm 28.8$ & $0.287 \pm 0.030$ & $384.2 \pm 62.9$ \\
\hline Middle & $1.101-1.110$ & $4.7 \pm 1.24$ & $1.43 \pm 0.45$ & $0.755 \pm 0.066$ & $260.1 \pm 33.5$ & $0.346 \pm 0.037$ & $172.2 \pm 38.3$ \\
\hline Bottom & $1.110-1.15$ & $1.4 \pm 0.36$ & $26.29 \pm 6.01$ & $0.584 \pm 0.070$ & $217.4 \pm 20.0$ & $0.427 \pm 0.050$ & $182.1 \pm 28.2$ \\
\hline
\end{tabular}

$n=10$. Values are mean \pm SE. Red cells suspended in BSKG at a hematocrit of $20 \%$ were layered on top of Stractan gradients of the specific gravities indicated in the table and centrifuged at $4^{\circ} \mathrm{C}$ for $45 \mathrm{~min}$ at $52,000 \mathrm{~g}$. Three fractions of red cells were collected separately and washed with $\mathrm{MgCl}_{2}$ and ouabain-binding buffer before determining their reticulocyte count, ouabain binding, and $\mathrm{Rb} / \mathrm{K}$ uptake.

there was no change in the number of pump units, there was a substantial increase in pump activity associated with the sickling process. On the other hand, ouabain-insensitive $\mathrm{Rb} / \mathrm{K}$ uptake decreased by an average of $42 \%$ after nitrogen incubation, from $198.7 \pm 90.4 \mathrm{nM} / 10^{9}$ cells/h to $116.7 \pm 13.2(P<0.01$ with paired comparison). There was a similar decrease of $\sim 35 \%$ in furosemide-sensitive $\mathrm{Rb} / \mathrm{K}$ uptake with deoxygenation (150.8 \pm 20.6 to $98.8 \pm 10.7)$.

After nitrogen incubation, intracellular sodium concentration in sickle erythrocytes increased significantly $(12.7 \pm 1.8$ to $21.2 \pm 2.1 \mathrm{mEq} /$ liter cells $)(P<0.01)$, and intracellular potassium concentration tended to decrease $(61.9 \pm 9.3$ to $56.9 \pm 5.5)$, although the latter change did not reach the level of significance.

Effect of deoxygenation and ouabain on the density distribution of cells (Figs. 1-4). The density distribution of cells was plotted for 16 sickle cell patients and seven control subjects. Normal (AA) erythrocytes, as depicted in Fig. 1, display a narrow range of density distribution. The blood of patients with sickle cell anemia, however, may exhibit a wide range of densities, with more high-density cells representing sickled cells and more low-density cells representing reticulocytes (Fig. 1). The DDC of blood from three patients with AS displayed the same configuration as did AA (data not shown).

Density distribution curves were plotted after $\mathrm{O}_{2}$ and $\mathrm{N}_{2}$ to examine the effect of deoxygenation on cell density. With deoxygenation of SS blood, the curve was shifted to the left by the increased percentage of heavier cells and very high density cells which represent sickled erythrocytes (Fig. 2). The percentage of cells heavier than the median-specific gravity in air was increased from 50 to $72 \pm 3 \%$ by deoxygenation $(n=9)$. Incubation in $\mathrm{O}_{2}$ did not alter the density distribution of normal or SS cells.
To evaluate the effect of inhibiting the sodium-potassium pump on the sickling process, we examined the density distribution of SS cells under nitrogen incubation in the absence and presence of $0.1 \mathrm{mM}$ ouabain. In each of eight experiments, ouabain reduced the percentage of very dense cells that appeared with nitrogen exposure (Fig. 3). The percentage of cells heavier than the median-specific gravity in nitrogen alone was reduced by ouabain from 50 to $25 \pm 6 \%$. Little or no effect was seen when ouabain was added to oxygenated SS cells (Fig. 4).

Effect of deoxygenation and ouabain on MCHC (Fig. 5). Hemoglobin and hematocrit were measured before and after nitrogen incubation. The MCHC of SS cells with deoxygenation increased in 11 of 12 cases by an average of $5.5 \pm 0.9 \%$, from $33.7 \pm 0.6$ to $35.3 \pm 0.9(P<0.01)$, reflecting shrinkage with sickling. MCHC of control erythrocytes did not change when they were deoxygenated. Ouabain, $10^{-4} \mathrm{M}$, prevented the increase in MCHC caused by deoxygenation of SS cells. Ouabain had no significant effect on MCHC in the control population.

\section{Discussion}

Abnormalities of cation transport have been described in association with sickling but the role of the sodium-potassium pump and associated changes in red cell water content have not been firmly established. Tosteson, Shea, and Darling first reported in 1952 (5) that oxygenated erythrocytes from patients with SS had slightly higher intracellular concentrations of sodium and lower concentrations of potassium than normal red blood cells. Incubation of SS cells in nitrogen, so as to produce sickling, resulted in a further gain in sodium and loss of potassium, whereas anoxia did not affect the cation content of normal erythrocytes. Follow-

Table IV. Effect of Deoxygenation on Na,K Transport Characteristics and Intracellular Electrolyte Concentrations of Erythrocytes

\begin{tabular}{|c|c|c|c|c|c|c|}
\hline & Ouabain binding & $\begin{array}{l}\text { Ouabain-sensitive } \\
\mathrm{Rb} / \mathrm{K} \text { uptake }\end{array}$ & $\begin{array}{l}\text { Ouabain-insensitive } \\
\mathrm{Rb} / \mathrm{K} \text { uptake }\end{array}$ & $\begin{array}{l}\text { Furosemide-sensitive } \\
\mathrm{Rb} / \mathrm{K} \text { uptake }\end{array}$ & $\begin{array}{l}\text { Intracellular } \\
\mathrm{Na} \text { concentration }\end{array}$ & $\begin{array}{l}\text { Intracellular } \\
\mathbf{K} \text { concentration }\end{array}$ \\
\hline & pmol/10 cells & nmol/110 cells/h & nmol/10 cells/h & $n m o l / 10^{9}$ cells/h & $m E q / l i t e r$ cells & mEq/liter cells \\
\hline \multicolumn{7}{|c|}{ Control (AA), $n=7$} \\
\hline Pre- $\mathrm{N}_{2}$ & $0.42 \pm 0.02$ & $112.9 \pm 7.7$ & $54.0 \pm 5.2$ & $50.14 \pm 5.00$ & $6.4 \pm 0.9$ & $84.2 \pm 2.3$ \\
\hline Post- $\mathrm{N}_{2}$ & $0.42 \pm 0.02$ & $127.5 \pm 11.9$ & $57.4 \pm 7.9$ & $48.3 \pm 3.08$ & $6.6 \pm 0.8$ & $82.1 \pm 1.8$ \\
\hline \multicolumn{7}{|c|}{ Sickle cells (SS), $n=11$} \\
\hline Pre- $\mathrm{N}_{2}$ & $0.69 \pm 0.04$ & $150.5 \pm 9.3$ & $198.7 \pm 90.4$ & $150.83 \pm 20.6$ & $12.7 \pm 1.8$ & $61.87 \pm 9.32$ \\
\hline Post- $\mathrm{N}_{2}$ & $0.65 \pm 0.05$ & $303.0 \pm 19.1^{*}$ & $116.7 \pm 13.2^{*}$ & $98.8 \pm 10.7^{*}$ & $21.2 \pm 2.1^{*}$ & $56.98 \pm 5.53$ \\
\hline
\end{tabular}

Values are mean \pm SE. $* P<0.01$ as compared with pre- $\mathrm{N}_{2}$ values. Red cells suspended in Hepes buffer at $\mathrm{pH} 7.4$ were deoxygenated by exposure to nitrogen in a shaking water bath at a temperature of $37^{\circ} \mathrm{C}$ for $2 \mathrm{~h}$. 


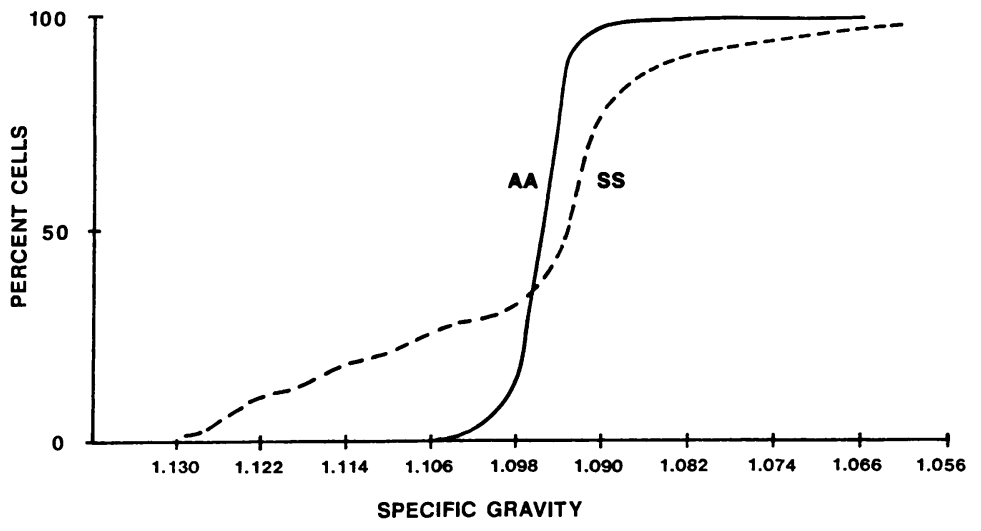

Figure 1. Density distribution of red cells from a representative sample of AA (solid line) and of SS (dashed line) blood under aerated conditions. Specific gravity of the phthalate ester is plotted on the abscissa and the percentage of cells heavier than each phthalate reference is plotted on the ordinate. Curves were drawn by eye through the data points obtained at intervals of 0.004 specific gravity. Normal erythrocytes display a narrow range of densities, whereas SS erythrocytes are distributed over a wider range. up studies of ion fluxes with isotopic tracers showed that sickling, again induced by exposure to nitrogen, greatly accelerated bidirectional fluxes of sodium and potassium in SS erythrocytes and increased lactate production, implying active transport (6, 7). Because these experiments were carried out just before the description of the Na-K-ATPase pump and its inhibition by ouabain in human red blood cells, the contribution of $\mathrm{Na}-\mathrm{K}$ ATPase-mediated ion fluxes to these phenomena was not specifically examined. Subsequently, the potassium efflux from deoxygenated red cells containing $\mathrm{Hb}-\mathrm{S}$ has often been used as an in vitro measure of red cell sickling, though it is now known to vary with $\mathrm{pH}$ (9). Clark, Morrison, and Shohet (18) reported both active and passive $\mathrm{Rb} / \mathrm{K}$ influx to be within the normal range in oxygenated SS cells, though the passive efflux rate of internal potassium was increased. Their experiments, it should be noted, were carried out on red cells that had been loaded with sodium by overnight storage at $4^{\circ} \mathrm{C}$, a procedure that would tend to minimize any difference in ouabain-sensitive $\mathrm{K}$ influx between SS and AA cells if a difference in internal sodium contributed to this. They did not assess the effect of sickling induced by deoxygenation. They noted an increase in Na-K-ATPase ac-
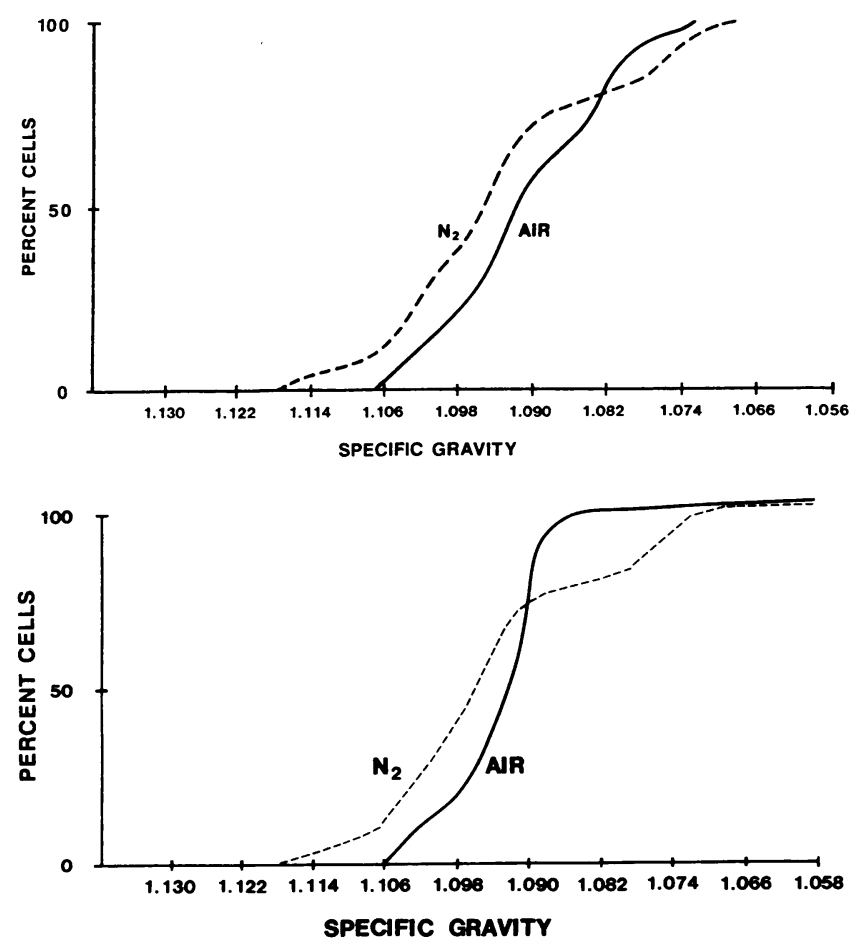

tivity in sickle cell membranes, especially in those separated cell fractions rich in reticulocytes, and ascribed the increase in enzymatic activity to the increased percentage of young erythrocytes, a conclusion reached also by Luthra and Sears (29). Berkowitz and Orringer recently reinvestigated the passive fluxes of $\mathrm{Na}^{+}$and $\mathrm{Rb}^{+}$in SS erythrocytes exposed to ouabain to eliminate active transport. While no difference was found in the influx of $\mathrm{Na}^{+}$or $\mathrm{Rb}^{+}$between oxygenated sickle cells and those of normal subjects, deoxygenation of sickle cells produced a substantial increase in the passive influx of $\mathrm{Na}^{+}$and $\mathrm{Rb}^{+}$that was not blocked by furosemide (30).

The effect of deoxygenation on the volume of SS red cells has been a subject of controversy, probably because of the varied experimental conditions employed by different investigators. Deoxygenation of sickle cell blood in vivo or in vitro produces a fall in the water content of erythrocytes $(5,31,32)$ but this has not always been observed $(4,6)$, especially when red cells have been separated and suspended in artificial media, from which calcium or magnesium may be omitted $(30,32,33)$. It is now clear that the effect of sickling on red cell volume is strongly influenced by $\mathrm{pH}(9,32)$ in that red cell shrinkage is retarded

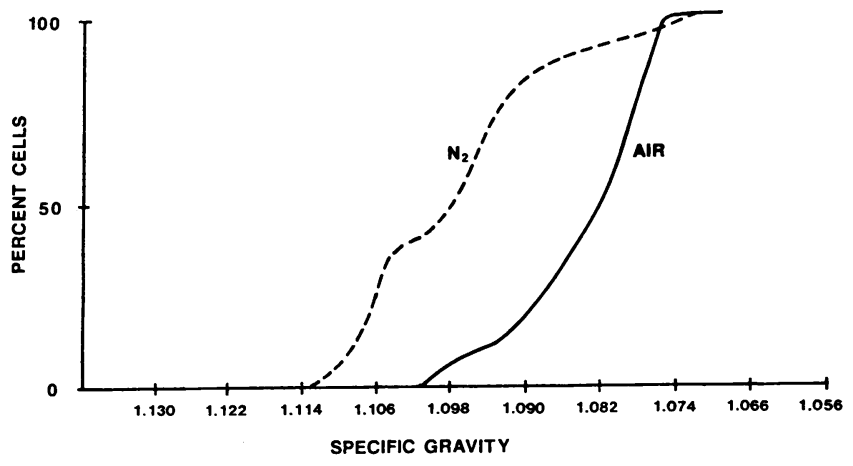

Figure 2. Density distribution of SS cells, aerated (solid line) and after nitrogen incubation (dashed line) from three representative patient studies. Specific gravity of the phthalate ester is plotted on the abscissa. The shift to the left with deoxygenation represents a larger percentage of heavier cells. 

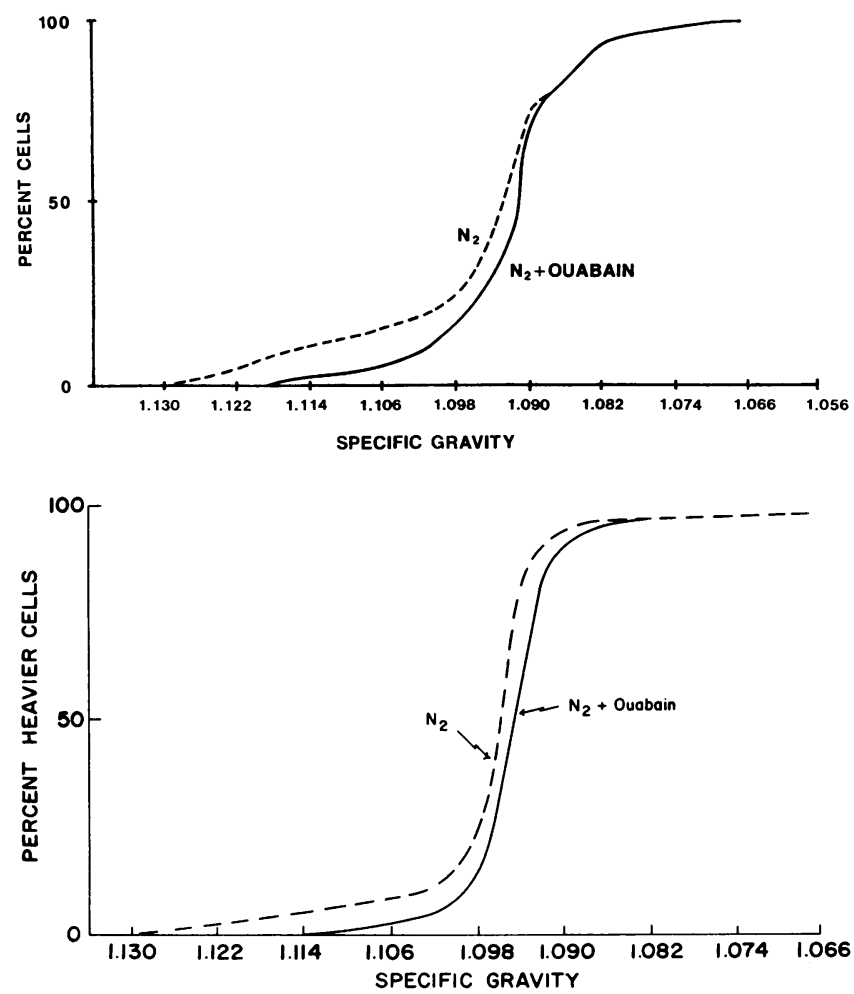

by $\mathrm{pH}$ greater than 7.4 and accelerated by acidic $\mathrm{pH}$. Sodium and potassium transport across red cell membranes is also affected by the presence or absence of divalent cations in the suspending medium (34).

The present studies demonstrate clearcut differences in transport characteristics between sickle cell erythrocytes and those of control patients, both related to and independent of the
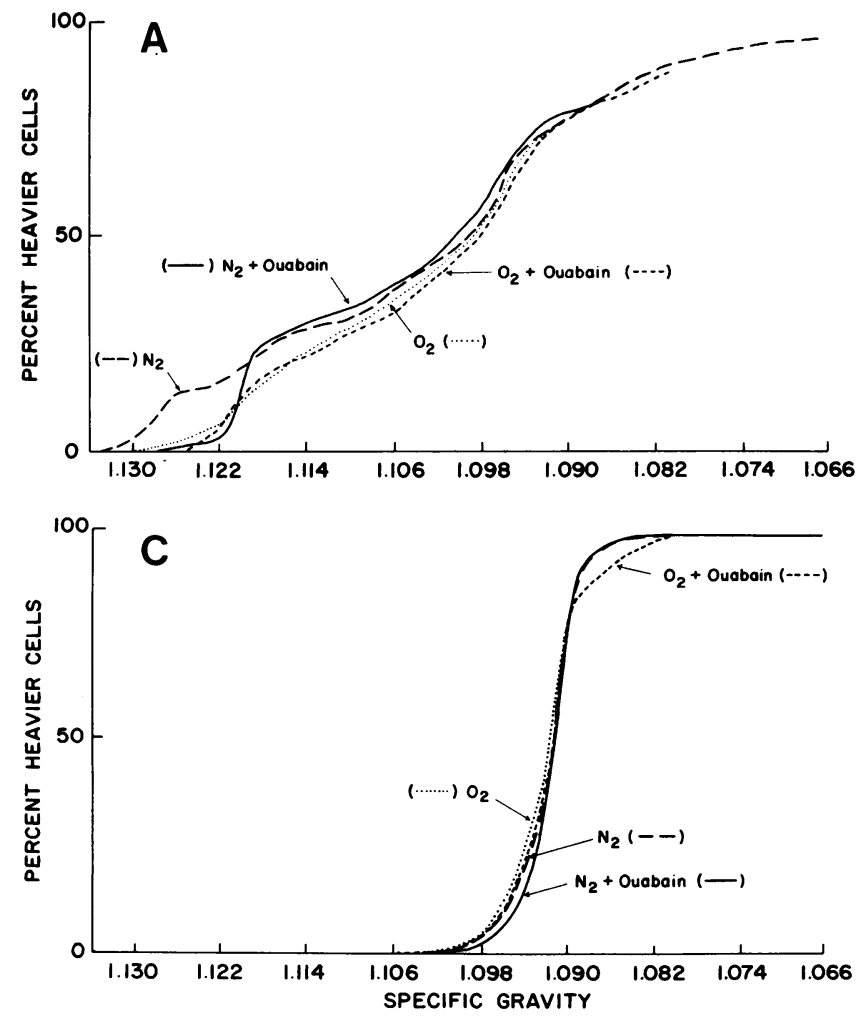

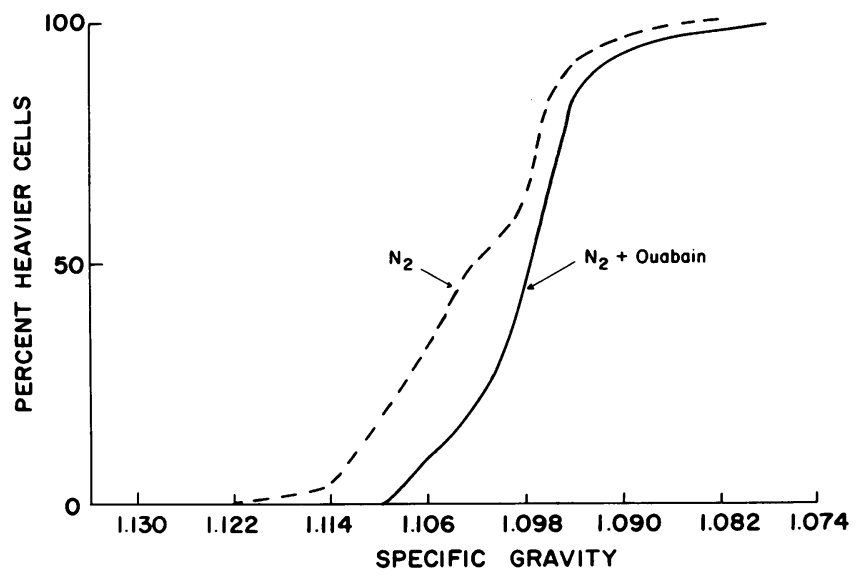

Figure 3. The effect of ouabain on the density distribution of SS cells deoxygenated by exposure to nitrogen for $2 \mathrm{~h}$. Three representative studies are shown. Incubation with $0.1 \mathrm{mM}$ ouabain during nitrogen exposure results in fewer of the heaviest (i.e., sickled) cells than with deoxygenation alone.

Na-K pump. Firstly, there are significantly more ouabain-binding sites in freshly drawn, aerated sickle red cells than in normal erythrocytes, together with an increase in Na-K-ATPase-mediated $\mathrm{Rb} / \mathrm{K}$ uptake. When cells are separated on density gradients, the fraction of SS cells containing the most reticulocytes also contains the highest number of ouabain-binding sites, suggesting that the increase in $\mathrm{Na}-\mathrm{K}$ pump units in sickle cell blood

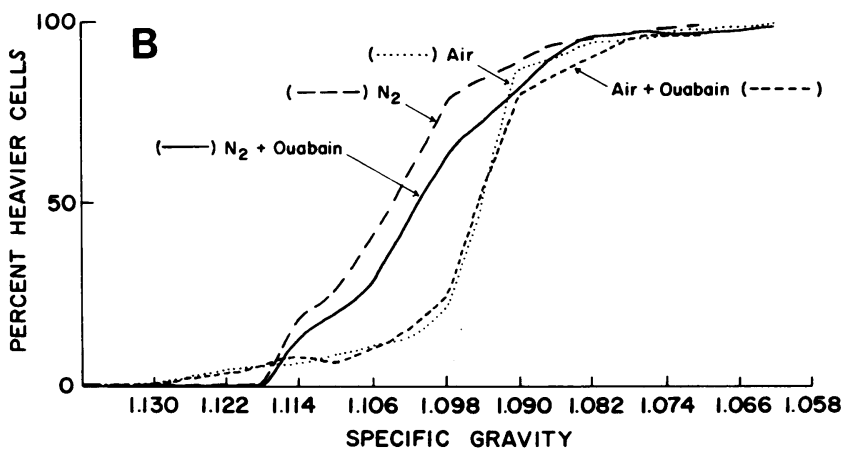

Figure 4. The effect of ouabain on the density distribution of SS cells exposed to nitrogen for $2 \mathrm{~h}$ is contrasted in $(A)$ and $(B)$ with its effect on aerated cells in two representative patients. $(C)$ illustrates the lack of effect of ouabain on oxygenated or deoxygenated cells in a control patient with SA. Results similar to this were obtained with AA erythrocytes. 


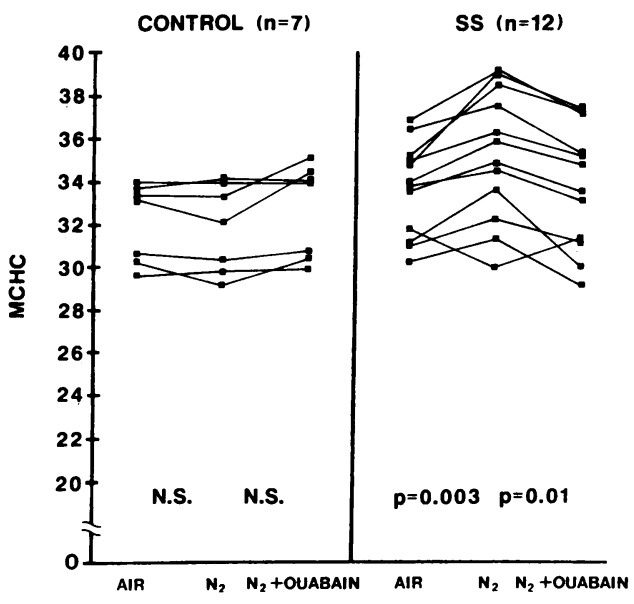

MEAN \pm SE $\quad 32.2 \pm 0.7 \quad 31.9 \pm 0.8 \quad 32.7 \pm 0.8 \quad 33.7 \pm 0.6 \quad 35.3 \pm 0.9 \quad 34.1 \pm 0.8$

Figure 5. The effect of nitrogen incubation and ouabain on MCHC of control and SS erythrocytes. MCHC is expressed as grams per deciliter.

is at least in part due to the large population of young red cells. These changes appear even more pronounced when a comparison is made with normal black control patients rather than with Caucasian controls, because black control subjects had diminished values of ouabain binding and $\mathrm{Rb} / \mathrm{K}$ uptake as compared with whites. The average levels of ouabain binding and $\mathrm{Rb} / \mathrm{K}$ uptake in SS erythrocytes was about twice those of red cells in normal black controls. These findings are consistent with those of Lasker and associates, who described a significantly decreased activity of $\mathrm{Na}-\mathrm{K}$-ATPase in erythrocytes of black subjects as compared with those of whites (35). The average red cell sodium content is significantly greater in normotensive blacks with AA hemoglobin than in their white counterparts (35-37). The present data suggest that this is the consequence of a reduction in the number of $\mathrm{Na} / \mathrm{K}$ pump units per cell. In SS erythrocytes, on the other hand, there appears to be an increase in sodium-potassium pump activity owing to two factors: an increase in ouabain-binding sites, largely due to the younger population of cells, and an increase in cell sodium. The combination of an increase in pump activity, together with an increase in cell sodium and a decrease in cell potassium, is consistent with an increased passive leak of $\mathrm{Na}^{+}$and $\mathrm{K}^{+}$in the red cells of patients with sickle cell anemia.

The influx of $\mathrm{Rb} / \mathrm{K}$ mediated by pump-independent, ouabain-resistant mechanisms is also substantially increased in aerated erythrocytes from sickle cell patients. About two-thirds of this flux could be inhibited by furosemide, implying that it was mediated by Na-K-Cl cotransport. In our experiments, ouabainresistant $\mathrm{Rb} / \mathrm{K}$ flux decreased when SS cells were deoxygenated. These findings differ from those of Berkowitz and Orringer, who reported no difference in "passive" ${ }^{86} \mathrm{Rb}$ influx between oxygenated red cells from sickle cell patients and normals, though in SS cells this parameter increased when cells were deoxygenated (30). Surprisingly, they found no evidence of Na-K-Cl cotransport in either oxygenated or deoxygenated SS cells. The reasons for these differences in results deserve further investigation.

The major finding of the present experiments is that the increase in $\mathrm{Rb} / \mathrm{K}$ influx produced by deoxygenation of sickle cells was entirely accounted for by marked acceleration of the Na-K-ATPase pump. The increase in ouabain-inhibitable Rb/ $\mathrm{K}$ influx seen in SS cells exposed to nitrogen was, in fact, greater in every case than the increase in total $\mathrm{Rb} / \mathrm{K}$ influx, so that when exposed to nitrogen, pump-independent uptake of ${ }^{86} \mathrm{Rb}$ decreased, including that portion sensitive to furosemide. The number of pump units per cell, as assessed by ouabain binding, did not change. The rise in internal concentrations of sodium seen in deoxygenated sickle cells is best interpreted as a consequence of the increase in passive influx of sodium first noted by Tosteson (7). This presumably stimulated the turnover of $\mathrm{Na}$ $\mathrm{K}$-ATPase, as reflected in the ratio of $\mathrm{Rb} / \mathrm{K}$ uptake to ouabain binding. At the same time, the reduction in sodium gradient across the red cell membrane would be expected to reduce the driving force for coupled entry of rubidium or potassium via the furosemide-sensitive $\mathrm{Na}-\mathrm{K}-\mathrm{Cl}$ transporter. The result of the deoxygenation of sickle red cells is therefore a massive increase, in absolute as well as proportionate terms, in ion transport driven by Na-K-ATPase. Because the pump extrudes $3 \mathrm{Na}^{+}$ions for every $2 \mathrm{~K}^{+}$that enter the cell, the increase in pump-mediated transport activity tends to reduce cell volume. A dehydrating effect of the red cell $\mathrm{Na}^{+} / \mathrm{K}^{+}$pump was demonstrated by Clark and her associates in normal red blood cells that were loaded with sodium by exposing them to nystatin (38). These authors also suggested that the pump might contribute to cell shrinkage in sickle cells in which intracellular sodium had been increased by deoxygenation. Inhibition of Na-K-ATPase in sickle cells might therefore be expected to increase cell volume, thereby reducing mean corpuscular hemoglobin concentration.

These predictions were borne out in the present experiments in which samples of sickle cell blood were deoxygenated by exposure to nitrogen. When sickle cells were deoxygenated, their $\mathrm{MCHC}$ increased, in 11 of 12 instances, by an average of $5.5 \%$. The addition of ouabain to SS cells under nitrogen prevented cell shrinkage and caused a decrease in MCHC. Density distribution studies were confirmatory. Nitrogen incubation increased the percentage of high-density cells in SS blood, and ouabain tended to reverse this change, reducing the number of highdensity cells.

These findings have an important implication for therapeutic strategies in sickle cell anemia. The predominance of pumpmediated active transport in SS erythrocytes and its magnification when these cells are deoxygenated suggest the possibility that inhibiting the Na-K-ATPase pump with cardiac glycosides might be useful in patients with sickle cell anemia by causing some degree of red cell swelling and thereby reducing the concentration of deoxyhemoglobin S. Ample evidence, both in vitro and in vivo, indicates that an increase in cell water reduces the tendency for SS cells to sickle (39-42) and thus may ameliorate certain clinical manifestations of sickle cell anemia (42). Furthermore, concentrations of cardiac glycosides that are nontoxic and can be achieved by therapeutic dosages of these drugs have been shown in subjects without sickle cell anemia to exert an inhibitory action on red cell $\mathrm{Na}-\mathrm{K}$-ATPase associated with an increase in red cell sodium and a fall in red cell potassium (43, 44) and, over several days, a small decrease in MCHC (45). Even a small decrease in the cellular concentration of deoxyhemoglobin $\mathrm{S}$ might exert a salutary effect in patients with sickle cell anemia because of the exponential relationship between MCHC and the delay time for gelation of sickle hemoglobin (1).

\section{Acknowledgments}

This research was aided by United States Public Health Service grants HL-15157, AM-18078, and RR-01032. 


\section{References}

1. Eaton, W. A., J. Hofrichter, and P. D. Ross. 1976. Delay time of gelation: a possible determinant of clinical severity in sickle cell disease. Blood. 47:621-627.

2. Noguchi, C. T., and A. N. Schechter. 1981. The intracellular polymerization of sickle hemoglobin and its relevance to sickle cell disease. Blood. 58:1057-1068.

3. Lux, S. E., K. M. John, and M. J. Karnovsky. 1976. Irreversible deformation of spectrin-actin lattice in irreversibly sickled cells. J. Clin. Invest. 58:955-963.

4. Op den Kamp, J. A. F., B. Roelofsen, and L. L. M. van Deenen. 1985. Structural and dynamic aspects of phosphatidylcholine in the human erythrocyte membrane. Trends Biochem. Sci. 10:320-323.

5. Tosteson, D. C., E. Shea, and R. C. Darling. 1952. Potassium and sodium of red blood cells in sickle cell anemia. J. Clin. Invest. 31:406411.

6. Tosteson, D. C., E. Carlsen, and E. T. Dunham. 1955. The effects of sickling on ion transport. I. The effect of sickling on $\mathrm{K}$ transport. $J$. Gen. Physiol. 39:31-53.

7. Tosteson, D. C. 1955. The effects of sickling on ion transport. II. The effect of sickling on sodium and cesium transport. J. Gen. Physiol. 39:55-67.

8. Glader, B. E., and D. G. Nathan. 1978. Cation permeability alterations during sickling: relationship to cation composition and cellular hydration of irreversibly sickled cells. Blood. 51:983-989.

9. Roth, E. F., Jr., R. L. Nagel, and R. M. Bookchin. 1981. pH dependency of potassium efflux from sickled red cells. Am. J. Hematol. 11:19-27.

10. Bookchin, R. M., and V. L. Lew. 1981. Effect of a "sickling pulse" on calcium and potassium transport in sickle cell trait red cells. J. Physiol. 312:265-280.

11. Izumo, H., S. Izumo, M. DeLuise, and J. S. Flier. 1984. Erythrocyte $\mathrm{Na}, \mathrm{K}$ pump in uremia. Acute correction of a transport defect by hemodialysis. J. Clin. Invest. 74:581-588.

12. Solomon, A. K. 1952. The permeability of the human erythrocyte to sodium and potassium. J. Gen. Physiol. 36:57-110.

13. Love, W. D., and G. E. Burch. 1953. A comparison of ${ }^{42} \mathrm{~K},{ }^{86} \mathrm{Rb}$ and ${ }^{134} \mathrm{Cs}$ as tracers of $\mathrm{K}$ in the study of cation metabolism of human erythrocytes in vivo. J. Lab. Clin. Med. 41:351.

14. Bernstein, J. C., and Y. Israel. 1970. Active transport of ${ }^{86} \mathrm{Rb}$ in human red cells and rat brain slices. J. Pharmacol. Exp. Ther. 174:323.

15. Wiley, J. S., and R. A. Cooper. 1974. A furosemide-sensitive cotransport of sodium plus potassium in the human red cell. J. Clin. Invest. 53:745-755.

16. Dunham, P. B., G. W. Stewart, and J. C. Ellory. 1980. Cl-activated passive potassium transport in human erythrocytes. Proc. Natl. Acad. Sci. USA. 77:1711-1715.

17. Corash, L. M., S. Pionelli, H. C. Chen, C. Seaman, and E. Gross. 1974. Separation of erythrocytes according to age on a simplified density gradient. J. Lab. Clin. Med. 84:147-151.

18. Clark, M. R., C. E. Morrison, and S. B. Shohet. 1978. Monovalent cation transport in irreversibly sickled cells. J. Clin. Invest. 62:329-337.

19. Rodgers, G. P., A. N. Schechter, and C. T. Noguchi. 1985. Cell heterogeneity in SC disease: quantitation of erythrocyte density profile. J. Lab. Clin. Med. 106:30-37.

20. Danon, D., and Y. Marikovsky. 1964. Determination of density distribution of red cell population. J. Lab. Clin. Med. 64:668-674.

21. Miale, J. B. 1982. Laboratory Medicine: Hematology. C. V. Mosby Co., St. Louis. Sixth ed. 875-876.

22. Beauge, L. A., and N. Adragna. 1971. The kinetics of ouabain inhibition and the portion of rubidium influx in human red blood cells. J. Gen. Physiol. 57:576-592.

23. Ellory, J.'C., and G. W. Stewart. 1982. The human erythrocyte Cl-dependent Na-K cotransport system as a possible mode for studying the action of loop diuretics. Br. J. Pharmacol. 75:183-188.
24. Furokawa, U., J. P. Bilezikian, and J. N. Loeb. 1981. Potassium fluxes in the rat reticulocyte. Ouabain sensitivity and changes during maturation. Biochim. Biophys. Acta. 649:625-632.

25. Weigensberg, A. M., and R. Blostein. 1983. Energy depletion retards the loss of membrane transport during reticulocyte maturation. Proc. Natl. Acad. Sci. USA. 80:4978-4982.

26. Kadluboroski, M., and P. S. Agutter. 1977. Changes in the activities of some membrane-associated enzymes during in vivo aging of the normal human erythrocyte. Br. J. Haematol. 37:111-125.

27. Panet, R., and H. Atlan. 1979. Inhibitory effects of two potassium ionophores on ouabain-resistant potassium fluxes in reticulocyte cell membrane. FEBS (Fed. Eur. Biochem. Soc.) Lett. 103:172-175.

28. Blostein, R., P. Drapeau, S. Benderoff, and A. M. Weigensberg. 1983. Changes in $\mathrm{Na}^{+}$ATPase and $\mathrm{Na}, \mathrm{K}$ pump during maturation of sheep reticulocytes. Can. J. Biochem. Cell Biol. 61:23-28.

29. Luthra, M. G., and D. A. Sears. 1982. Increased $\mathrm{Ca}^{++}, \mathrm{Mg}^{++}$and $\mathrm{Na}^{+}-\mathrm{K}^{+}$-ATPase activities in erythrocytes of sickle cell anemia. Blood. 60:1332-1336.

30. Berkowitz, L. R., and E. P. Orringer. 1985. Passive sodium and potassium movements in sickle erythrocytes. Am. J. Physiol. 18:C208C214.

31. Masys, D. R., A. Bromberg, and S. P. Balcerzak. 1974. Red cells shrink during sickling. Blood. 44:885-889.

32. Fabry, M. E., and R. L. Nagel. 1982. The effect of deoxygenation on red cell density: significance for the pathophysiology of sickle cell anemia. Blood. 60:1370-1377.

33. Fales, F. W. 1978. Water distribution in blood during sickling of erythrocyte. Blood. 51:703-708.

34. Ellory, J. C., P. W. Flatman, and G. W. Stewart. 1983. Inhibition of human red cell sodium and potassium transport by divalent cations. J. Physiol. 340:1-17.

35. Lasker, N., L. Hopp, S. Grossman, R. Bamforth, and A. Aviv. 1985. Race and sex differences in erythrocyte $\mathrm{Na}^{+}, \mathrm{K}^{+}$, and $\mathrm{Na}^{+}-\mathrm{K}^{+}$. adenosine triphosphatase. J. Clin. Invest. 75:1813-1820.

36. Love, W. D., and G. E. Burch. 1953. Plasma and erythrocyte sodium and potasşium in a group of southern white and negro blood donors. J. Lab. Clin. Med. 41:258-267.

37. Munro-Faure, A. D., D. M. Hill, and J. Anderson. 1971. Ethnic differences in human red blood sodium concentration. Nature (Lond.). 231:457-458.

38. Clark, M. R., J. C. Guatelli, A. T. White, and S. B. Shohte. 1981 Study on the dehydrating effect of the red cell $\mathrm{Na} / \mathrm{K}$ pump in nystatintreated cells with varying $\mathrm{Na}^{+}$and water contents. Biochim. Biophys. Acta. 646:422-432.

39. Clark, M. R., J. C. Guatelli, N. Mohandas, and S. B. Shohet. 1980. Influence of red cell water content on the morphology of sickling. Blood. 55:823-830.

40. Clark, M. R., N. Mohandas, and S. B. Shohet. 1982. Hydration of sickle cells using the sodium ionophore monensin. J. Clin. Invest. 70: 1074-1080.

41. Schmidt, W. F., T. Asakura, and E. Schwartz. 1982. Effect of cetiedil on cation and water movements in erythrocytes. J. Clin. Invest. 60:589-594.

42. Rosa, R. M., B. E. Bierer, R. Thomas, J. S. Stoff, M. Kruskall, S. Robinson, H. F. Bunn, and F. H. Epstein. 1980. A study of induced hyponatremia in the prevention and treatment of sickle cell crisis. $N$. Engl. J. Med. 303:1138-1143.

43. Kramer, H. J., K. Glanzer, T. Freitag, et al. 1985. Studies on the role of sodium- and potassium-activated adenosine triphosphatase inhibition in the pathogenesis of human hypertension. Klin. Wochenschr. 63:32-36.

44. Astrup, J. 1974. The effect of hypokalemia and digoxin therapy on red cell sodium and potassium content. Some clinical aspects. Scand. J. Clin. Lab. Invest. 33:11-16.

45. Kettlewell, M., A. Nowers, and R. White. 1972. Effect of digoxin on human red blood cell electrolytes. Br. J. Pharmacol. 44:165-167. 